Western North American Naturalist 69(4), (C) 2009, pp. 548-550

\title{
RECORDS OF THE YELLOW-NOSED COTTON RAT (SIGMODON OCHROGNATHUS) IN SOUTHWESTERN NEW MEXICO
}

\begin{abstract}
Keith Geluso ${ }^{1}$
ABSTRACT.-The yellow-nosed cotton rat (Sigmodon ochrognathus) previously was known only from extreme southwestern New Mexico in the Peloncillo and Animas mountains. Here I document S. ochrognathus at 3 localities from the Big Burro and Mogollon mountains in southwestern New Mexico. My northernmost capture represents an extra-limital record of $160 \mathrm{~km}$ north of prior records in southern New Mexico and represents the northernmost occurrence in North America. Lack of intensive mammalian surveys in the region render it difficult to interpret my recent captures, but the most parsimonious explanation is that captures likely represent overlooked populations. I captured S. ochrognathus in grassy areas ungrazed by domestic livestock along the Gila River. Understanding the use of limited grassland habitats along arid rivers by terrestrial vertebrates in the region is important because many of these grasslands have been converted to agricultural lands or are grazed by livestock.
\end{abstract}

Key words: Sigmodon ochrognathus, yellow-nosed cotton rat, New Mexico, range expansion, distribution.

In New Mexico, the yellow-nosed cotton rat (Sigmodon ochrognathus) is known from the Animas and Peloncillo mountains in southern Hidalgo County, where it occurs from higherelevation grasslands to pine-oak forests (Findley et al. 1975). This species generally inhabits rocky hillsides containing bunchgrass, agaves, prickly pears, oaks, and other shrubs (Findley et al. 1975, Findley 1987, Cook 1986). In Arizona, it also occurs in grassy habitats in southern mountains (Hoffmeister 1986, Davis and Ward 1988).

Herein, I report on new distributional records for $S$. ochrognathus in southwestern New Mexico. Individuals were trapped in Sherman live traps baited with mixed seeds during brief exploratory surveys of small terrestrial mammals in the region, while I conducted research on bats (e.g., Geluso 2007). Trapping was initiated because I observed runways of small mammals that resembled those constructed by Sigmodon in an area where no published records of Sigmodon were known (Findley et al. 1975). I also personally examined whether unpublished voucher material existed at the Museum of Southwestern Biology, University of New Mexico, Albuquerque (MSB) and the Gila Center for Natural History, Western New Mexico University, Silver City (WNMU). I further contacted biologists regarding potential records of $S$. ochrognathus in the region. My voucher specimens were deposited in the United States Geological Survey, Biological Survey Collection at MSB.

On 31 March 2003, I captured an adult female (MSB catalog number 124219) in an array of 20 traps at the north end of the Big Burro Mountains, Grant County (T17S, R17W, NE1/4, Sec. $21 ; 32^{\circ} 48.914^{\prime} \mathrm{N}, 108^{\circ} 35.963^{\prime} \mathrm{W}$; elevation $1330 \mathrm{~m}$ ). This individual had a body weight of $66 \mathrm{~g}$, was lactating, and contained 5 embryos with the largest uterine swelling measuring $8 \mathrm{~mm}$. On 1 April 2003, I captured and released another female from the same trap array. Both females were captured in a grassy depression along a gravel road. The road was situated immediately above the floodplain of the Gila River in an area ungrazed by domestic livestock. Runways of Sigmodon were observed only in areas with dense matted grasses. Adjacent slopes were xeric, and dominant shrubs were honey mesquite (Prosopis glandulosa) and catclaw acacia (Acacia greggii). No other animal was captured in the trap array. I set another 50 traps in the area, but traps were not in dense grasses. In this trap array, I captured Ord's kangaroo rats (Dipodomys ordii) and a cactus mouse (Peromyscus eremicus).

On 8 April 2003, I captured a nonreproductive female (body weight $57 \mathrm{~g}$; MSB 124221)

${ }^{1}$ Department of Biology, University of Nebraska at Kearney, Kearney, NE 68849. E-mail: gelusok1@unk.edu 
in an array of 40 traps set in the Big Burro Mountains, Grant County (T17S, R17W, NW1/4, Sec. 16; 32 $50.012^{\prime} \mathrm{N}, 108^{\circ} 36.430^{\prime} \mathrm{W}$, elevation $1350 \mathrm{~m}$ ). This individual was captured on a grassy hillside above but near the floodplain of the Gila River. The location was on an ungrazed gravelly slope, and dominant plants included bush muhly (Muhlenbergia), three-awn (Aristida), mustard, honey mesquite, and catclaw acacia. Additional rodents captured included Bailey's pocket mouse (Chaetodipus baileyi), rock pocket mouse (Chaetodipus intermedius), Merriam's kangaroo rat (Dipodomys merriami), Ord's kangaroo rat (D. ordii), western harvest mouse (Reithrodontomys megalotis), and western white-throated woodrat (Neotoma albigula).

On 26 June 2006, I captured a subadult male (MSB 125022) in the floodplain near the confluence of Mogollon Creek and the Gila River along the southwestern edge of the Mogollon Mountains (Grant County, $10 \mathrm{mi}$ E Buckhorn; $33^{\circ} 02.553^{\prime} \mathrm{N}, 108^{\circ} 31.817^{\prime} \mathrm{W}$, elevation $1410 \mathrm{~m}$ ). This individual weighed $44 \mathrm{~g}$ and had testes that measured $8 \times 5 \mathrm{~mm}$ in length. It was captured in tall grasses and forbs in an ungrazed area that was fenced. The ungrazed area measured about $225 \times 75 \mathrm{~m}$, and plants were about $1.2-1.8 \mathrm{~m}$ in height. Dominant trees surrounding the grassy area consisted of Arizona sycamores (Platanus wrightii), Rio Grande cottonwoods (Populus deltoides wislizeni), and junipers. Other species of mammals captured in the 40 traps included the white-footed mouse (Peromyscus leucopus), western harvest mouse (R. megalotis), hispid pocket mouse (C. hispidus), and hispid cotton rat (S. hispidus).

These records represent the northernmost records of S. ochrognathus in North America (Hall 1981, Hoffmeister 1986, Davis and Dunford 1987). The nearest published record to my northernmost locality at the edge of the Mogollon Mountains is $140 \mathrm{~km}$ to the southwest in the Chiricahua Mountains of Arizona (Hoffmeister 1986), and the nearest record in New Mexico is $160 \mathrm{~km}$ to the south in the Animas Mountains (Cook 1986). Frey (2004:22), in her annotated checklist of the mammals in New Mexico, reported this species from the "vicinity of the Big Burro Mountains in Grant County," but details of specific location, dates of occurrence, habitat associations, and voucher specimens were not presented. However, neither J.K. Frey nor I have been able to find voucher specimens of S. ochrognathus from Grant County to substantiate that statement (J.K. Frey personal communication).

My recent captures of $S$. ochrognathus in the Big Burro and Mogollon mountains could represent a recent expansion in distribution or overlooked populations that have always occurred in the area. Davis and Dunford (1987) postulated a generalized northward range expansion for S. ochrognathus in Arizona. However, lack of intensive mammalian surveys in the Gila River region of New Mexico renders it difficult to interpret my captures. Frey (2009) suggested that records representing shifts in distribution should be based only on conclusive evidence. If conclusive evidence is not available, extra-limital records should be viewed as previously undocumented populations. Within this framework, the most parsimonious explanation of my records from the Big Burro and Mogollon mountains is that captures of S. ochrognathus represent previously undocumented populations. Only limited past surveys of mammals have been conducted along the Gila River in the vicinity of my captures (Bailey 1931). Bailey (1928) reported limited visits to the area by biologists (6-9 November 1906 and 5-12 October 1908), and there are no recent published works on surveys of mammals in the area, although some unpublished specimens from the region are housed in collections at WNMU. Thus, the limited surveys of small mammals along the Gila River, the rather disjunct occurrence of $S$. ochrognathus across its range (Findley and Jones 1960), and the apparently low abundance of individuals compared to other Sigmodon (Baker 1969) suggest that S. ochrognathus might always have occurred in the area. However, the possibility that the records represent a range expansion cannot be excluded.

Captures of S. ochrognathus in upland habitats of desert mountains are expected for this species (Findley and Jones 1960, Baker 1969). However, the capture of an individual in a grassy floodplain with another species of Sigmodon is unusual because competitive interactions between species appear important in determining local distributions (Baker 1969). In the Mexican states of Chihuahua and Coahuila, for example, S. ochrognathus occurs at higher elevations than the hispid cotton rat (Baker 1956, Anderson 1972). In Arizona, 
Hoffmeister (1986) reported that S. ochrognathus is found rarely in association with other species of Sigmodon. I suspect my capture of the subadult adjacent to the Gila River likely represents a dispersing individual from a nearby hillside rather than an individual from a local population in the floodplain. Additional surveys of small mammals in the area are needed to support or refute this hypothesis.

All individuals of S. ochrognathus reported herein were captured in areas ungrazed by domestic livestock. Although considered the most xerophilous species in the genus Sigmodon (Baker 1969, Baker and Shump 1978), S. ochrognathus still requires adequate vegetative cover for many runways (Hoffmeister 1963, 1986). Baker (1969) suggests that the preferred habitat of S. ochrognathus has been altered where grazing has been severe, but this species can persist on rocky hillsides with limited grass. In a study comparing grazed and ungrazed habitats in the southwestern United States, S. ochrognathus was captured almost exclusively in ungrazed habitats (Jones et al. 2003). Understanding the use of limited grassland habitats along arid rivers by terrestrial vertebrates in the region is important because many have been converted to agricultural lands or are grazed by domestic livestock. These riverine habitats may support and benefit a number of vertebrates that are restricted to or closely associated with them.

I thank C. Ramotnik (U.S. Geological Survey, Biological Survey Collection, MSB) and R. Jennings (WNMU) for their assistance in museum matters and M. Ramsey, P. Barnhill, and J. Baumberger (National Forest Service, Silver City Ranger District) for providing assistance in obtaining a special-use permit to conduct research on federal lands. Discussions with J.K. Frey on definitions of range expansions have helped shape my ideas on this topic. I also thank J.K. Frey, K.N. Geluso, and 2 anonymous reviewers for comments on earlier versions of this manuscript.

\section{Literature Cited}

Anderson, S. 1972. Mammals of Chihuahua: taxonomy and distribution. Bulletin of the American Museum of Natural History 148:149-410.
Bailey, F.M. 1928. Birds of New Mexico. New Mexico Department of Game and Fish, Santa Fe.

Bailey, V. 1931. Mammals of New Mexico. North American Fauna 53:1-412.

BaKer, R.H. 1956. Mammals of Coahuila, Mexico. University of Kansas Publications, Museum of Natural History 9:125-335.

1969. Cotton rats of the Sigmodon fulviventer group. Pages 177-232 in J.K. Jones, Jr., editor, Contributions in mammalogy: a volume honoring Professor E. Raymond Hall. Museum of Natural History, University of Kansas, Lawrence.

BaKer, R.H., AND K.A. Shump, Jr. 1978. Sigmodon ochrognathus. Mammalian Species 97:1-2.

Cook, J.A. 1986. The mammals of the Animas Mountains and adjacent areas, Hidalgo County, New Mexico. Occasional Papers, Museum of Southwestern Biology 4:1-45.

Davis, R., And C. Dunford. 1987. An example of contemporary colonization of montane islands by small, nonflying mammals in the American Southwest. American Naturalist 129:398-406.

Davis, R., AND O.G. WaRD. 1988. A vacant "Microtus niche" now occupied by the yellow-nosed cotton rat (Sigmodon ochrognathus) on an isolated mountain in southeastern Arizona. Journal of Mammalogy 69: 362-365.

FindLEY, J.S. 1987. The natural history of New Mexican mammals. University of New Mexico Press, Albuquerque.

Findley, J.S., A.H. Harris, D.E. Wilson, and C. Jones. 1975. Mammals of New Mexico. University of New Mexico Press, Albuquerque.

FindLEY, J.S., AND C.J. JonES. 1960. Geographic variation in the yellow-nosed cotton rat. Journal of Mammalogy 41:462-469.

FreY, J.K. 2004. Taxonomy and distribution of the mammals of New Mexico: an annotated checklist. Occasional Papers, Museum of Texas Tech University 240:1-32. .2009. Distinguishing range expansions from previously undocumented populations using background data from museum records. Diversity and Distributions 15:183-187.

GeLuso, K. 2007. Winter activity of bats over water sources and flyways in New Mexico. Southwestern Naturalist 52:482-492.

Hall, E.R. 1981. The mammals of North America. 2nd edition. John Wiley \& Sons, New York, 2:601-1181 +90 .

Hoffmeister, D.F. 1963. The yellow-nosed cotton rat, Sigmodon ochrognathus, in Arizona. American Midland Naturalist 70:462-469.

. 1986. Mammals of Arizona. University of Arizona Press, Tucson.

Jones, Z.F., C.E. Bock, And J.H. Bock. 2003. Rodent communities in a grazed and ungrazed Arizona grassland, and a model of habitat relationships among rodents in southwestern grass/shrublands. American Midland Naturalist 149:384-394.

Received 2 March 2008 Accepted 28 May 2009 